мислення, удосконалення фахових умінь та навичок у майбутній діяльності, підвищення навчальної та ділової компетенції.

\title{
Література
}

1. Бандурка О. М. Основи педагогічної техніки / О.М.Бандурка, В. О. Тюрина, О. І. Федоренко. - Х. : ТИТУЛ, 2006. - 176 с. 2. Вітвицька С. Основи педагогіки вищої школи: підруч. за модульно-рейтинговою системою навчання для студентів магістратури / С. Вітвицька. К. : Центр навч. літ., 2006. - 384 с. 3. Кайдалова Л. Г. Модульна технологія навчання: [навч.метод. посіб. для викладачів і студентів вищ. навч. закладів] / Л. Г. Кайдалова, 3. М. Мнушко. Х. : Вид-во НФАУ: Золоті сторінки. - 2002. - 86 с. 4. Методика проведення занять у вищому навчальному закладі: метод. реком. [для викладачів] / [Л. Г. Кайдалова, О. О. Телєжкіна, С. М. Полуян та ін.] - Х. : Вид-во НФаУ. - 2004. - 60 с. 5. Нагаєв В. М. Методика викладання у вищій школі: [навч. посіб.] / В. М. Нагаєв. - К. : Центр учбової літ., 2007. - 232 с. 6. Слєпкань 3. I. Наукові засади педагогічного процесу у вищій школі: [навч. посіб.] / 3. І. Слєпкань. - К. : Вища школа, 2005. - 239 с.

УДК 159.92

Г. В. Дьяконов,

доктор психол. наук, професор, Кіровоградський державний педагогічний університет імені Володимира Винниченка

\section{ДІАЛОГІЧНА КОНЦЕПЦІЯ ГУМАНІТАРНО-КУЛЬТУРНОЇ ОСВІТИ НА ПСИХОЛОГО-ПЕДАГОГІЧНОМУ ФАКУЛЬТЕТІ}

\begin{abstract}
Дьяконов Г. В. Діалогічна концепція гуманітарно-культурної освіти на психологопедагогічному факультеті.

У статті аналізується й обгрунтовується діалогічний підхід до побудови концепції гуманітарнокультурної освіти на психолого-педагогічному факультеті. Розкриваються засади, принципи, аспекти і перспективи розроблення і впровадження цієї концепції в практику професійної підготовки майбутніх практичних психологів і соціальних педагогів.

Ключові слова: діалогічний підхід, гуманітарно-культурна освіта, професійна підготовка майбутніх практичних психологів і соціальних педагогів.
\end{abstract}

Дьяконов Г. В. Диалогическая концепция гуманитарно-культурного образования на психологопедагогическом факультете.

В статье анализируется и обосновывается диалогический подход к построению концепции гуманитарно-культурного образования на психолого-педагогическом факультете. Раскрываются основы, принципы, аспекты и перспективы разработки и внедрения данной концепции в практику профессиональной подготовки будущих практических психологов и социальных педагогов.

Ключевые слова: диалогический подход, гуманитарно-культурное образование, профессиональная подготовка будущих практических психологов и социальных педагогов.

Diakonov H. V. Dialogic concept of human-cultural education in psychology and teachers'training faculty.

In the article analysed and grounded dialogical approach to the conception of humanitarian-cultural education on a psychological-pedagogical faculty. Grounds, principles, aspects and prospects of development and introduction of this conception in practice of professional preparation of future practical psychologists and social teachers, open up.

Key words: dialogical approach, humanitarian-cultural education, professional preparation of future practical psychologists and social teachers.

Теоретико-методологічні дослідження новітніх парадигм освіти й розвитку особистості у психології та педагогіці переконливо свідчать, що ідея діалогу і діалогічний світогляд органічно поєднують у собі культуроформувальний і гуманітарно-духовний потенціали становлення людини, громадянина, фахівця, творця $[4 ; 9 ; 10 ; 13]$. 
Фундаментальність і універсальність філософсько-психологічної парадигми діалогу полягає в тому, що вона втілює в собі екзистенційні принципи людського буття i розкриває фундаментальні онтологічні закономірності розвитку і саморозвитку людини, взаємодії i взаємовпливу людей, шляху становлення свободи i творчості особи, особливості розвитку і саморозвитку груп і колективів, соціальних організацій і спільнот $[1 ; 2 ; 3 ; 6]$.

Незважаючи на зростаючу увагу до вивчення особливостей, закономірностей діалогу і потенціалу діалогічного підходу у психології $[4 ; 6 ; 7 ; 9 ; 10 ; 11 ; 12 ; 13]$ і педагогіці [5; 8], донині в науці виконано мало досліджень ролі і можливостей діалогічного підходу в розбудові гуманітарно-культурної освіти на психолого-педагогічному факультеті.

Унаслідок цього метою статmі є теоретико-методологічне вивчення особливостей, закономірностей і можливостей діалогічного підходу в обгрунтуванні і побудові концепції гуманітарно-культурної освіти на психолого-педагогічному факультеті.

Основні теоретико-методологічні положення психології діалогу, що визначають ідейно-змістовне підгрунтя гуманітарно-діалогічної концепції вищої освіти майбутніх педагогів і психологів, окреслені у філософсько-гуманітарних працях таких мислителів і науковців, як М. Бахтін [1], М. Бубер [3], С. Франк [14], В. Біблер [2], а також у працях сучасних психологів Т. Флоренської [13], Г. Ковальова [9], А. Копйова [10], Г. Кучінського [11] та ін.

Сучасна філософія і психологія діалогу визрівала в напруженому і драматичному пошуку видатних вітчизняних представників духовно-етичної філософії М. Бахтіна, М. Бердяєва， С. Булгакова， Л. Карсавіна， О. Лосєва， В. Зеньковського， С. Франка, П. Флоренського та ін.

Прагнення російських й українських мислителів і науковців визначити витоки «соборності» і вивільнити потенціали «Софійної всеєдності»є тим живим і плідним підгрунтям, на якому зростали сучасні ідеї діалогу і духовності як органічного розвитку онтолого-екзистенційних витоків буття і життя. Вітчизняні мислителі й дослідники завжди визначали розвиток моральної, релігійної та культурної свідомості в прямому зв'язку 3 формами людського спілкування, а можливість морально-духовного вдосконалення розглядали як продуктивний наслідок міжлюдського й загальнолюдського спілкування, єдності й соборності, духовного і культурного обміну.

Отже, у працях видатних вітчизняних і зарубіжних мислителів і науковців розроблено основи діалогічної парадигми й діалогічного підходу у психології й педагогіці як фундаментальної основи організації навчально-виховного процесу у вищій школі, як основи гуманізації й гуманітаризації професійно-особистісного становлення майбутніх педагогів і психологів.

Відправними пунктами в побудові теоретико-методологічної концепції гуманітарнокультурної освіти i професійно-особистісного становлення майбутніх педагогів i психологів є сучасні дослідження в галузі філософії, психології та педагогіки діалогу [413], а також досвід методико-практичної організації навчально-виховного процесу на психолого-педагогічному факультеті Кіровоградського державного педагогічного університету імені В. Винниченка [6].

Головна ідея - і гіпотеза - концепції гуманітарно-діалогічної освіти на психологопедагогічному факультеті полягає в тому, що парадигма діалогу може бути основою гуманітарно-духовного, особово-соціального, культурно-громадянського і професійнопрактичного становлення майбутніх бакалаврів, фахівців і магістрів у галузі психології й педагогіки.

Науково-теоретична сфера гуманітарно-діалогічної концепції вищої освіти на психологічному факультеті визначається розвитком теоретико-методологічного розуміння філософії, психології, психотерапії та педагогіки діалогу і послідовним впровадженням досягнень і результатів методологічного дослідження теорії діалогу в науково-теоретичну і навчально-виховну роботу. 
Основними аспектами і напрямами гуманітарно-діалогічної концепції навчання, життя i професійного становлення майбутніх соціальних педагогів і практичних психологів $\epsilon$ науково-теоретична, організаційно-конструктивна, методико-практична i соціогуманітарна сфери життя студентів i викладачів психолого-педагогічного факультету.

Діалогічний підхід і діалогічна логіка дослідження створюють основу для вивчення взаємозв'язку діалогу 3 іншими фундаментальними категоріями психологічної й педагогічної науки - діяльністю, спілкуванням, навчанням, грою, відносинами, смислом, творчістю тощо, а також діалогічного взаємозв'язку між фундаментальними психологічними явищами: свідомістю й особистістю, спілкуванням і особистістю, свідомістю і спілкуванням, мисленням і спілкуванням, спілкуванням і вихованням, спілкуванням і самовихованням, навчанням і спілкуванням, навчанням і саморегуляцією тощо [6].

Теоретичне дослідження психології діалогу зумовлює необхідність дослідження діалогічної природи таких явищ, як психічні процеси, психічні стани і психічні особливості особистості, серед яких першочерговий інтерес становлять мислення, мова, почуття, уява, воля, характер, здібності тощо.

Унаслідок унікальної науково-теоретичної глибини й універсальної багатошаровості парадигми діалогу вона постає як оригінальний i фундаментальний світогляд, який виявляється у різноманітних сферах і аспектах навчально-наукової і життєво-практичної діяльності майбутнього педагога і психолога, - гуманітарія і практика, а тому може служити основою гуманітарно-культурного й особистісно-духовного становлення сучасного фахівця-психолога.

Організаційно-конструктивна сфера гуманітарно-діалогічної концепції навчальновиховного процесу на психолого-педагогічному факультеті визначається конструктивними можливостями і перспективами застосування діалогічної парадигми для розроблення стратегії, принципів і організаційних форм гуманізації та гуманітаризації навчально-виховного процесу.

Теоретичний аналіз навчального плану показує, що він містить багато навчальних дисциплін, що мають явний або неявний діалогічний зміст. Навчальними дисциплінами 3 експліцитним діалогічним змістом є: психологія спілкування, психологія конфлікту, соціальна психологія, психологія діалогу, індивідуально-психологічне консультування, діалогічний практикум, гуманістична психологія. $€$ також багато навчальних дисциплін, що мають імпліцитний діалогічний зміст: загальна психологія, вікова і педагогічна психологія, психологія сім'ї, психокорекція, основи психотерапії, політична психологія, теорія і методологія психології, психологія духовного розвитку, експериментальна психологія, психологія важкої дитини тощо.

Послідовне вивчення і осягнення діалогічного змісту і перспектив діалогічного розуміння багатьох навчальних дисциплін в процесі науково-теоретичного становлення фахівця-психолога $\epsilon$ цікавою i важливою перспективою розвитку «всеєдиного» гуманітарно-діалогічного світогляду майбутніх практичних психологів і соціальних педагогів.

Виявлення гуманітарно-діалогічного змісту багатьох психологічних проблем і напрямів науково-практичних розробок $є$ також важливим аспектом у процесі науково-дослідної роботи студентів і викладачів психологічного факультету. Наприклад, за останні роки студенти психолого-педагогічного факультету Кіровоградського педагогічного університету активно i різнобічно досліджували такі гуманітарно-діалогічні теми: діалогічна природа моральних почуттів; психологія сорому, провини і совісті; психологія прощення і любові; психологія щирості і довіри; психологія надії в юнацькому віці; психологія смислу життя; психологія егоцентризму й емпатії; психологія внутрішнього діалогу; діалог у гештальт-терапії, діалог у психодрамі, психологія щоденника i внутрішній діалог особистості; діалог у психотерапії та психологічному консультуванні. 
Діалогічний підхід у навчанні психологів є конструктивною основою психологічних концепцій активного навчання і спілкування (активних методів навчання і спілкування), оскільки діалогічні уявлення можуть визначатися як фундаментальні принципи і моделі основних форм і методів активного навчання і спілкування: проблемного навчання, програмованого навчання, структурно-образного навчання, особистісно-групового навчання, творчих форм навчання.

Діалогічний підхід $є$ конструктивно-методологічним фундаментом теорії й практики професійної діяльності психолога й соціального педагога, оскільки уявлення про три парадигми (і рівні) психолого-педагогічного дослідження [6; 9] - об'єктну, суб'єктну та інтерсуб'єктну - $є$ основою для парадигмального розрізнення й парадигмального визначення основних форм практичної психологічної роботи - психодіагностики, психокорекції та психотерапії.

Певна міра діалогічності $\epsilon$ неодмінною властивістю всіх трьох форм (i рівнів) практичної психологічної діяльності: психодіагностики, психокорекції та психотерапії (консультування). Проте, ми вважаємо, що традиційна психодіагностика найменше діалогічна; психокорекція вже включає деякі діалогічні моменти і процеси, а психотерапія i консультування найповніше втілюють діалогічну сутність людини і багатоманітного світу перетворених форм діалогічної реальності.

Методико-практична сфера гуманітарно-діалогічної концепції на психологопедагогічному факультеті, на наш погляд, охоплює багато різноманітних проблем i відкриває майже неосяжні перспективи впровадження нових навчально-методичних i професійно-практичних форм діяльності, проте більшість 3 них недостатньо досліджені теоретично і практично.

У колі методико-практичних проблем психолого-педагогічної вищої освіти ми визначаємо такі основні напрями застосування гуманітарно-діалогічного підходу: поперше, розроблення і впровадження діалогічної концепції активних методів навчання; подруге, створення цілісної діалогічної концепції психопрактичної підготовки фахівцяпсихолога i соціального педагога; по-третє, організація професійно-психологічної практики у світлі гуманітарно-діалогічної концепції освіти психологів-професіоналів.

Гуманітарно-діалогічна ідеологія грунтується не на законах і принципах ієрархічності, згідно з яким вищі рівні «знімають» (або навіть знецінюють) сутнісний зміст нижчих рівнів, а на принципах і законах діалогічної взаємодоповнюваності, згідно 3 якими важливим є не будь-який один рівень аналізу, а саме їхнє конкретне поєднання. Без уявлення про рівні й парадигми діалогічної методології та методології психопрактичної діяльності стають неможливими аналіз та інтерпретація складних і поліфонічних явищ гуманітарно-діалогічного буття людини з людиною - в повсякденному житті і навчальновиховному процесі на психолого-педагогічному факультеті.

Одним із перших серйозних наслідків вище наведеної трирівневої схеми психопрактичної діяльності психолога $є$ обгрунтування змісту, програми й етапів організації і проведення професійно-психологічної практики на психолого-педагогічному факультеті.

Програмне забезпечення психологічної практики концептуально подане в «Наскрізній робочій програмі навчально-професійної практики» і програмах психологічної практики студентів II - V-го курсів та магістрів.

Соціогуманітарна сфера діалогічної концепції психологічної освіти на психологопедагогічному факультеті $\epsilon$ фундаментальною основою i характеристикою всіх компонентів цієї концепції (тобто науково-теоретичної, організаційно-конструктивної і методико-практичної сфер). Інакше кажучи, зміст соціогуманітарності, принципи іiі існування і феномени іiі вияву пронизують всі ці компоненти в різноманітних формах. Водночас соціогуманітарна сфера постає як органічний складник цієї концепції в єдності всіх її компонентів, але такою ж мірою вона $є$ і відносно самостійною сферою діалогічної концепції навчально-виховного процесу на психолого-педагогічному факультеті. 
Незважаючи на підвищений інтерес до проблем гуманізації і гуманітаризації у визначенні фундаментальних принципів і перспектив сучасної освіти, серед педагогів i психологів відсутне загальноприйняте розуміння цих понять. Тому в працях багатьох науковців ці поняття часто трактуються як синонімічні або як незалежні один від одного. На наш погляд, необхідний i можливий конструктивний розгляд співвідношення цих понять з позицій діалогічно-інтерсуб'єктної концепції.

Сутність гуманізації ми бачимо в реалізації антропоцентричності-«людиномірності» процесів навчання і виховання, що виражається в забезпеченні суб'єктно-діяльнісної, індивідуально-особистісної орієнтації навчально-виховного процесу.

Сутність гуманітаризації ми пов'язуємо із забезпеченням глибокої та поліфонічної культурної антропоморфізації освітнього процесу, змістом якого $є$ інтерсуб'єктноціннісна, духовно-трансперсональна інтенційність буття молодої людини і становлення студента як «людини в світі» та «людини у Всесвіті».

3 погляду культурології, прийняті визначення означають, що поняття гуманізації відповідає цивілізаційно-техногенному світогляду, а поняття гуманітаризації виражає цінності культурно-духовного світоставлення.

Таке розуміння гуманізації та гуманітаризації дозволяє співвіднести ці поняття відповідно - із суб'єктним та інтерсуб'єктно-діалогічним рівнями (парадигмами), що є основою нашої гуманітарно-діалогічної концепції педагогічної та психологічної освіти.

Гуманітарно-діалогічне розуміння професійно-особистісного становлення фахівцівпсихологів і соціальних педагогів виходить з уявлення про «живе знання» (С. Франк) i «живе життя» кожного студента і студентських колективів (курсів, груп, факультету) в реальній цілісності й унікальності їх змісту, розвитку і перспектив. Унаслідок цього здійснення гуманізації та гуманітаризації навчання і виховання майбутніх психологів і педагогів передбачає не стільки планування певних заходів, скільки вимагає створення багатопланового гуманітарно-діалогічного середовища, що $\epsilon$ реальним i наповнене подіями життя студентів і викладачів. Водночас ми бачимо сенс і в тому, щоб розглядати деякі основні напрямки i форми реалізації гуманізації й гуманітаризації навчання i виховання студентів у контексті гуманітарно-діалогічної концепції вищої освіти психологів і педагогів.

Основними напрямами забезпечення гуманізації навчання i виховання в процесі навчально-професійного становлення майбутніх психологів $\epsilon$ : реалізація індивідуального і диференціального підходу в навчанні, актуалізація «людиномірного» потенціалу змісту навчальних дисциплін, утвердження принципів суб'єктно-особистісних (взаємоповага і взаємна вимогливість викладача і студента, забезпечення свободи і відповідальності, створення різноманітних зворотних зв'язків), упровадження особистісно-творчих завдань у навчально-науковій діяльності, сприяння розвитку студентської демократії, оптимізація соціально-психологічного клімату тощо.

Основними напрямами i формами втілення гуманітаризації навчально-виховного процесу у професійно-особистісному становленні майбутніх практичних психологів i соціальних педагогів є: утвердження діалогічно-фасилітативних взаємовідносин між викладачами i студентами; створення атмосфери довіри, відвертості, підтримки, емпатичного розуміння; забезпечення можливостей особової і професійно-психологічної самоактуалізації під час навчальних занять шляхом організації психологічних тренінгів (рольового спілкування, сензитивності, емпатичного слухання, саморегуляції, психосинтезу, нейролінгвістичного програмування,психодрами, гештальт-терапіі); розширення духовно-культурного горизонту особистості під час вивчення таких навчальних дисциплін, як «Психологія релігії», «Психологія духовного розвитку», «Психологія діалогу» та ін.

Важливу роль у гуманізації і гуманітаризації особистісно-професійного становлення майбутніх психологів і педагогів відіграє впровадження гуманістичного стилю в організації психологічної практики студентів, а також розгортання соціально-культурної 
діяльності студентів у навчально-виховних і культурно-творчих закладах і установах м. Кіровограда й області.

Розроблена нами діалогічна концепція гуманізації і гуманітаризації навчальновиховного процесу на психолого-педагогічному факультеті $\epsilon$ першим кроком на шляху теоретико-концептуального осмислення досвіду професійно-особистісної освіти майбутніх практичних психологів і соціальних педагогів.

Звичайно, діалогічна концепція гуманізації й гуманітаризації навчально-виховного процесу на психолого-педагогічному факультеті Кіровоградського державного педагогічного університету імені В. Винниченка не $є$ універсальною, вичерпною й остаточно завершеною. Водночас ми вважаємо, що обгрунтована концепція окреслює важливі напрями подальшого розроблення цієї концепції i, на наш погляд, вона відкриває широкі можливості iii подальшого розвитку, творчого вдосконалення i практичного втілення у практику навчально-виховної роботи на психолого-педагогічних факультетах.

\section{Література}

1. Бахтин М. М. Проблемы поэтики Достоевского / М. М. Бахтин. - М. : Советская Россия, 1979. - 320 с. 2. Библер В. С. От наукоучения - к логике культуры: Два философских введения в двадцать первый век / В. С. Библер. - М. : Изд. полит. литературы, 1991. - 413 с. 3. Бубер М. Два образа веры / М. Бубер. - М. : Республика, 1995. - 468 с. 4. Братченко С. Л. Диагностика личностно-развивающего потенциала : [метод. пособ. для школьных психологов] / С. Л. Братченко. - Псков : Изд-во Псковского областного института повышения квалификации работников образования, 1997. - 64 с. 5. Дмитриева Л. Г. Диалогический подход к формированию психологической готовности будущего учителя к субъект-субъектному педагогическому взаимодействию : автореф. дис. на соискание ученой степени докт. пед. наук / Л. Г. Дмитриева. Москва, 2011. 6. Дьяконов Г. В. Основы диалогического подхода в психологической науке и практике / Г. В. Дьяконов. - Кировоград : Полиграфия, 2007. - 847 с. 7. Емельянов Ю. Н. Обучение паритетному диалогу / Ю. Н. Емельянов. - Л. : Изд-во ЛГУ, 1991. - 107 с. 8. Зазулина Л. В. Дидактико-діалогічна модель підвищення кваліфікації вчителя / Л. В.Зазулина // Освіта і управління. - 1999. - Том 3. - № 1. - С.123-134. 9. Ковалев Г. А. Психология воздействия : автореф. дис. на соискание ученой степени докт. психол. наук / Г. А. Ковалев- М. : Изд-во НИИОиПП АПН СССР, 1991. - 51 с. 10. Копьев А. Ф. Взаимоотношение «Я»-«Другой» и его значение для практической психологии / А. Ф. Копьев // Московский психотерапевтический журнал. - 1999. - № 2. - С. 48-60. 11. Кучинский Г. М. Психология внутреннего диалога / Г. М. Кучинский. - Минск : Университетское, 1988. - 206 с. 12. Панферов В. Н. Диалог и общение / В. Н. Панферов // Человек в мире диалога : [тезисы докладов и сообщений всесоюзной конференции]. -Л. : АН СССР, 1990. - С. 100-102. 13. Флоренская Т. А. Диалог в практической психологии / Т. А. Флоренская. - М. : Изд-во НИИОПП, 2006. - 244 с. 14. Франк С. Л. Непостижимое. Онтологическое введение в философию религии : Сочинения / С. Л. Франк. - М. : Правда, 1990. - С. 183-559.

УДК 378.126+337.134: 371.11

B. I. Жuгipb, кандидат пед. наук, доцент, Бердянський державний педагогічний університет

\section{УПРАВЛІНСЬКА КОМПЕТЕНТНІСТЬ ЯК НЕОБХІДНА УМОВА ПРОФЕСІОНАЛІЗМУ МЕНЕДЖЕРА ОСВІТИ}

Жигірь В. І. Управлінська компетентність як необхідна умова професіоналізму менеджера освіти.

Статтю присвячено проблемі формування управлінської компетентності менеджера освіти як необхідної умови його професіоналізму. У ній розглядаються підходи до визначення поняття, розкривається структура управлінської компетентності менеджера освіти. Схарактеризовано особливості економічного, планово-прогностичного, стратегічного, організаційного, контролюючого, інформаційно-аналітичного компонентів управлінської компетентності менеджера освіти. 